\title{
Comparative Leaching Tests of Gold from Unroasted and Roasted Pyrite Using Microwave Radiation
}

\author{
CATALIN ALEXANDRU BARBU ${ }^{1,2}$, NICOLAE TOMUS ${ }^{3}$, AURA DANIELA RADU ${ }^{3 *}$, \\ MARIUS ZLAGNEAN ${ }^{3}$, DIANA MARIA BANU ${ }^{3}$ \\ ${ }^{1}$ University Politehnica of Bucharest, Faculty of Materials Science and Engineering, 313 Splaiul Independenţei, 060042, Bucharest, \\ Romania \\ ${ }^{2}$ The National Bank of Romania, 25 Lipscani Str., 030031, Bucharest, Romania \\ ${ }^{3}$ The Research and Development National Institute for Radioactive Metals and Resources, 70 Carol I Blvd., 020917, Bucharest, Romania
}

\begin{abstract}
Recently, the application of microwaves as a source of energy to the extractive industry has received particular attention from a large number of researchers. During the mid-1960s to 1988 most researches focused on the behavior of microwave radiant materials. These research activities continue to be important as long as the fundamental data on microwave interaction with materials is important for the successful application of technologies. This article presents the comparative cyanide tests of unprocessed and non-fired pyrite as well as the technical indicators obtained in these tests. After performing comparative cyanidation tests on unroasted and roasted pyrites at 400 and $700^{\circ} \mathrm{C}$ it was found that there was no significant reduction in lime and cyanide consumption for roasted pyrite at $400^{\circ} \mathrm{C}$ but for the roasted pyrite at $700^{\circ} \mathrm{C}$ the consumption of lime is reduced from $110 \mathrm{~kg} \cdot t^{-1}$ to $10 \mathrm{~kg} \cdot \mathrm{t}^{-1}$, cyanide is reduced from $2.8 \mathrm{~kg} \cdot \mathrm{t}^{-1}$ to $1.76 \mathrm{~kg} \cdot \mathrm{t}^{-1}$, and yields of leaching increase from $50 \%$ for unroasted pyrite at $81 \%$ for roasted pyrite.
\end{abstract}

Keywords: leaching, cyanide, gold recovery, microwave

\section{Introduction}

Compared with pyrometallurgy-hydrometallurgical extraction of metals from their ores is potentially highly attractive. This attractiveness is attributed to economic, environmental, and technical reasons. It is often less costly and less harmful to the environment by avoidance of hazardous gases emissions such as $\mathrm{SO}_{2}$.

In addition, metals can be obtained directly in pure form from leach solution or recovered from impure leach solution.

Factors such as the relatively mild corrosion issues compared to refractory lining consumption in smelting operations; low temperature processing; low handling cost of leaching products; possibility of treatment of low-grade ores and the scale of operation make leaching more preferable than high temperature smelting.

However, some problems may arise during hydro-metallurgical operations. These include: low recovery of extracted metal, difficulties in solid-liquid separation and effect of impurities on the ease of purification. The principal disadvantage of hydrometallurgical operations is probably the process times required to achieve high metal recovery since these processes are often carried out at low temperatures compared to pyrometallurgical processes.

Microwave assisted leaching has been investigated in an attempt to improve the yield of extracted metal and to reduce process time, especially with the increasing demand for more environmentally friendly processes [1-6]. Unique microwave heating characteristics are the main driver for potential implementation in metal extraction. These include: low processing time, direct, selective and volumetric heating, and a more controllable heating process.

For the efficient recovery of gold from ore, cyanidation has been widely used in extractive metallurgy for the past 100 years.

*email: daniela_aura_radu@yahoo.com 
Recently, considerable attention on non-cyanide lixiviants has been arisen in the metallurgical industry due to the increasing environmental concerns over cyanidation $[7,8]$.

Popescu et al. [9] have recently investigated the application of ionic liquids (ILs) to selectively recover of precious metals ( $\mathrm{Ag}$ and $\mathrm{Au}$ ) from the anodic slime obtained at the anodic dissolution of cast e-waste.

A roasting process using electric furnaces and high-pressure oxidation has been used to decompose pyrites in $\mathrm{Au}$ concentrates. However, the roasting process is uneconomical and involves environmental problems $[10,11]$. A microwave process has been reported as an alternative for the roasting process. It has many advantages, such as being selective to specific substances, using a non-contact method from the energy source, rapid and uniform energy transfer, and convenient operation in terms of generation source manipulation $[12,13]$.

Previous studies have reported on the microwave treatment for various minerals. Uslu et al. [13] conducted research on the desulfurization of coals using microwaves. Huang and Rowson [14] treated pure pyrite and marcasite using microwaves in a mid-temperature $\left(50^{\circ} \mathrm{C}\right)$ nitric acid solution. Ma et al. [15] studied the microwave treatment for the removal of sulfur and arsenic in Au concentrate. Amankwah et al. [16] reported the use of microwaves as a pretreatment process for gold recovery from carbonaceous sulfide concentrate by cyanide leaching. However, few studies have explained the relationship between the microwave irradiation and the enhancing leaching efficiency of Au from the gold concentrate.

Knowing that minerals and gold concentrates [17] have good electromagnetic coupling with microwave radiation. INTEC SA, in partnership with INCDMRR, has developed an experimental fluid bed microwave processing facility to improve the extraction of the precious metals.

\section{Materials and methods}

The microwave generators include microwave generator device, waveguide transmission line, fluid bed processor microwave applicator, fluidization agent source, cyclone gas-cyclone separator and a reactor neutralizing the reaction products.

The resonant metal cavity has an internal diameter $\mathrm{D}=100 \mathrm{~mm}$, a height $\mathrm{H}=440 \mathrm{~mm}$ and is made of AISI 316 refractory stainless steel. The microwave radiation emission device is a magnetron type which continuously emits a microwave radiation with the frequency $\mathrm{f}=2.45 \mathrm{GHz}$ (wavelength $\lambda_{\mathrm{o}}=$ $12.24 \mathrm{~cm}$ ). The directing of microwave radiation to the processing area is provided by a rectangular waveguide transmission line type WR $284(\mathrm{a}=72.4 \mathrm{~mm}, \mathrm{~b}=34 \mathrm{~mm})$ through which the microwaves propagate into the $\mathrm{TE}_{10}$ fundamental module (Figure 1).

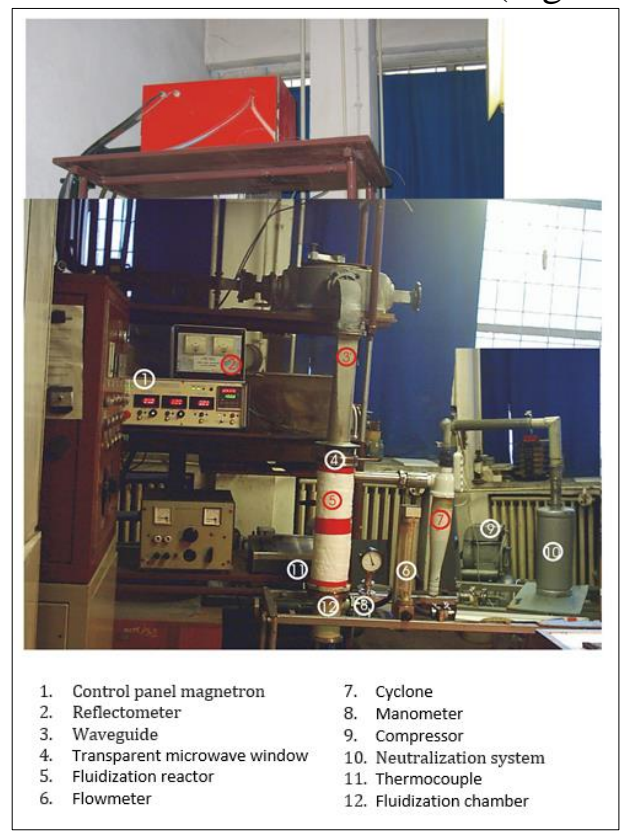

Figure 1. The fluidized-bed microwave heating system as laboratory demonstration model 


\section{Results and discussions}

Sulphur roasting is an essential operation of the extraction processes of non-ferrous metals, especially as it is at the forefront of treatment schemes and it partly conditions the success of subsequent operations.

Following the studies conducted over time $[11,12]$, it can be admitted that the oxidation of iron sulphides leads mainly to oxides: $\mathrm{Fe}_{2} \mathrm{O}_{3}$ and $\mathrm{Fe}_{3} \mathrm{O}_{4}$, but there might be a thin layer of sulfate whose reaction with residual FeS is very fast. This sulphate is highlighted very hard by most of the methods of analysis used [18, 19].

Since the frying atmosphere is obligatory oxidizing, stable compounds in the frying gases are: $\mathrm{O}_{2}$, $\mathrm{N}_{2}, \mathrm{SO}_{2}, \mathrm{SO}_{3}, \mathrm{H}_{2} \mathrm{O}$ and $\mathrm{CO}_{2}$. Instead, $\mathrm{CO}, \mathrm{H}_{2}, \mathrm{NH}_{3}, \mathrm{H}_{2} \mathrm{~S}, \mathrm{CS}_{2}$ and $\mathrm{S}_{2}$ can only be present in very small concentrations, so their influence can be neglected.

There is only one important balance between the gaseous sulfur oxides stable constituents:

$$
\mathrm{SO}_{2}+1 / 2 \mathrm{O}_{2}=\mathrm{SO}_{3}
$$

At low temperatures, the above reaction evolves with $\mathrm{SO}_{3}$ but at low reaction rate in the absence of the catalyst an equilibrium is reached. At temperatures above $700^{\circ} \mathrm{C}$, the equilibrium of the reaction moves to the left, but the presence in most of the roasted ores of oxides that can serve as $\mathrm{SO}_{3}$ forming catalysts, results in $\mathrm{SO}_{2}$ and $\mathrm{SO}_{3}$ concentrations close to the steady state concentrations.

Knowing the water avidity of $\mathrm{SO}_{2}$ resulted from the pyrite roasting, the gases were directed from the overflow of the cyclone to a buffer tank containing $\mathrm{Ca}(\mathrm{OH})_{2}$ solution at a $p \mathrm{H}=12$.

In the presence of water $\mathrm{SO}_{2}$ was converted into $\mathrm{H}_{2} \mathrm{SO}_{3}$ according to the reaction:

$$
\mathrm{SO}_{2}+\mathrm{H}_{2} \mathrm{O}=\mathrm{H}_{2} \mathrm{SO}_{3}
$$

The sulphurous acid thus formed is oxidized in time and at warmth it converted into sulfuric acid.

As a result of sulphurous acid formation, the calcium hydroxide solution, having an alkaline character and a $p \mathrm{H}=12$, was converted to an acidic solution with a $p \mathrm{H}=3.5$, an acidity of $17.47 \mathrm{~g} \cdot \mathrm{L}^{-1} \mathrm{H}_{2} \mathrm{SO}_{3}$ and a normality of $0.426 \mathrm{~N}$.

Calcium hydroxide in the presence of sulfuric acid is converted to calcium sulphate according to the reaction:

$$
\mathrm{Ca}(\mathrm{OH})_{2}+\mathrm{H}_{2} \mathrm{SO}_{4}=\mathrm{CaSO}_{4} \downarrow+2 \mathrm{H}_{2} \mathrm{O}
$$

Using the experimental model, two attempts were made for roasting the golden pyrite in the Baia Mare area, which had the following main elements in the chemical composition: $\mathrm{Fe}_{2} \mathrm{O}_{3}=53.73 \%, \mathrm{~S}=$ $42.3 \%, \mathrm{Au}=8.0 \mathrm{~g} \cdot \mathrm{t}^{-1}$ and $\mathrm{Ag}=54 \mathrm{~g} \cdot \mathrm{t}^{-1}$.

Two fluid bed frying operations were performed, one at $400^{\circ} \mathrm{C}$ and the other one at $700^{\circ} \mathrm{C}$. After 16 min it was necessary to interrupt the power supplied by the magnetron so that the temperature inside the applicator did not rise above $750^{\circ} \mathrm{C}$.

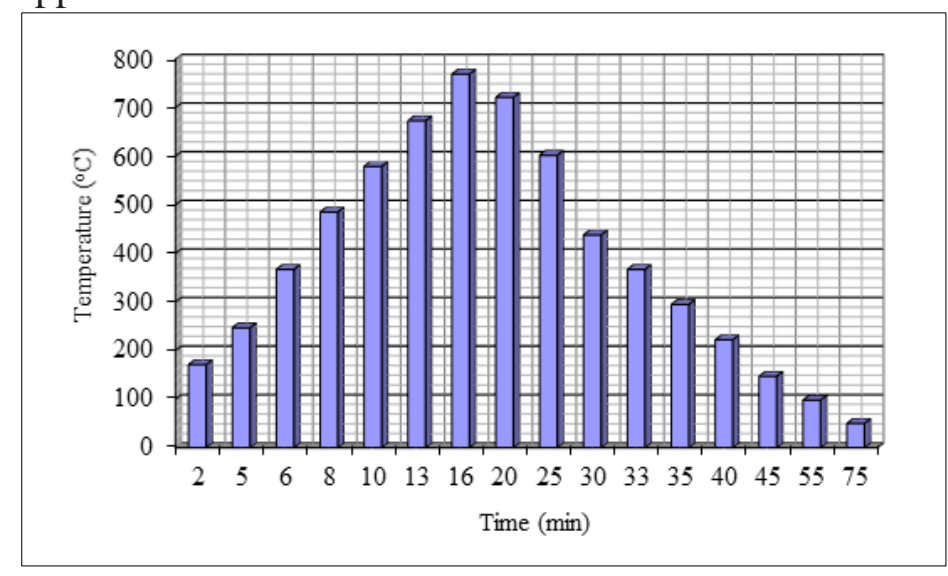

Figure 2. Temperature variation inside the microwave appliance during pyrite roasting 
Before and after roasting, both samples were analyzed chemically and by scanning electron microscopy (SEM) coupled with EDX elemental analysis electron microscopy as follows:

- From the SEM image presented at the electron microscope (Figure 3a), it can be observed almost perfect pyrite crystals of 40-80 microns with unaltered surfaces, as well as other new granules resulting from crushing (possibly aluminosilicate type).

- Roasted pyrite (Figures 3b, 3c) shows oxidized particles with irregular shapes and porous surfaces. It is seen from the EDX spectrum analysis of some crystals a significant increase in the iron and oxygen content and a decrease in the sulfur content. Sulfur content decreased in some crystals to $1.55 \%$, iron increased to $61.5 \%$, while oxygen reached up to $31.89 \%$ for SEM images and EDX spectra taken before (a) and after pyrite roasting (b and c). The high content of iron, oxygen and sulfur leads to the assumption of a high degree of incompleteness of the sample.

When the metal surface is exposed to cyanide-containing solutions and the presence of cyanide is the limiting reactant, the dissolution rate of the metal increases directly proportional to the free cyanide concentration present in the solution. This is valid until the maximum dissolution rate is reached. Again, another increase in cyanide concentration may have a slight slowing effect on dissolution rate.

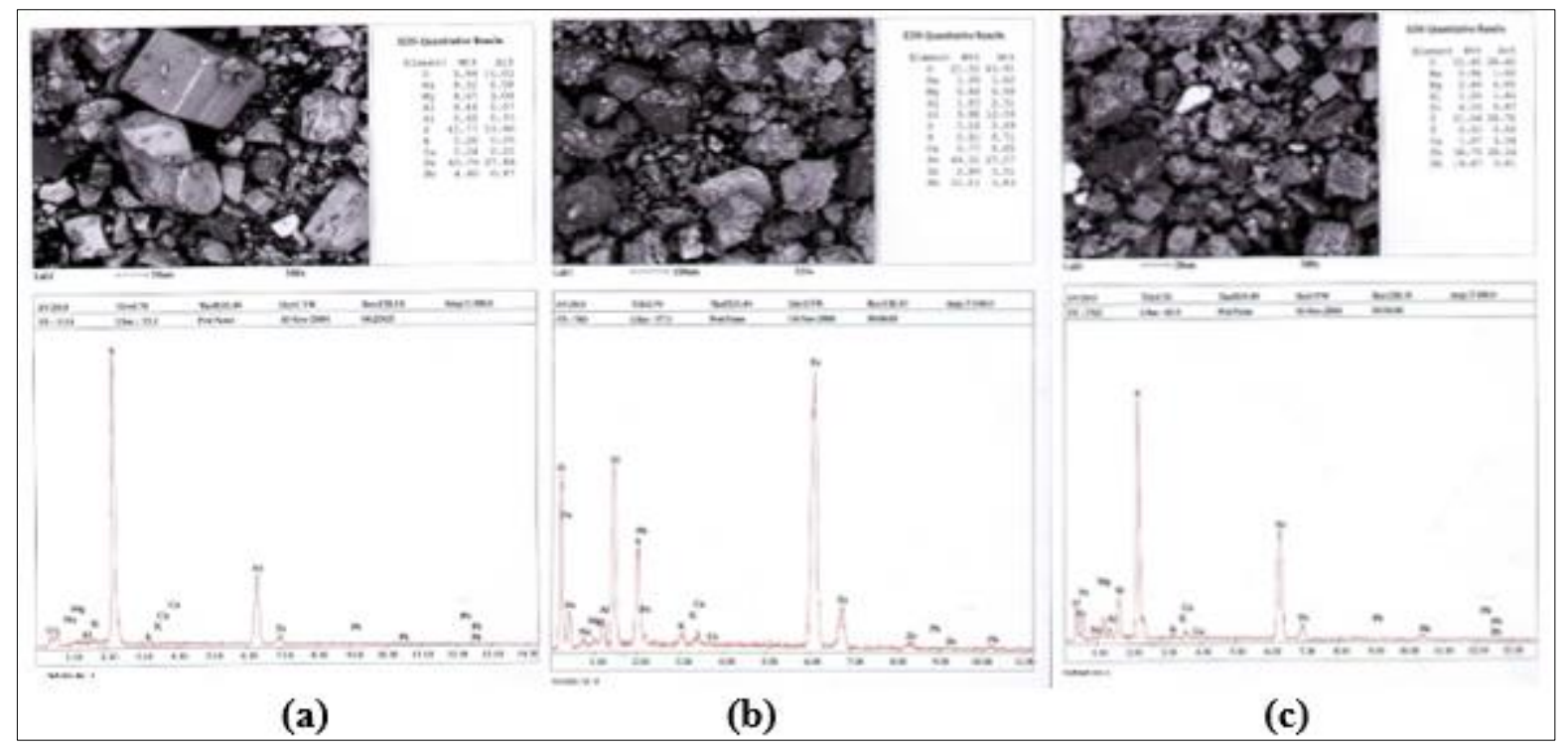

Figure 3. Images taken from the electronic microscope after roasting ( $a, b$ and $c)$

In order to study the influence of the microwave heating reduction process on the leaching efficiency of a refractory cyanuric pyrite, the study of the cyanide leaching of three samples of pyrite, two of which were treated in the microwave fields, and one representing the "raw" pyrite, not fried as it was harvested from the field.

\section{- The leaching of gold from the unroasted pyrite}

This method consisted of introducing $0.5 \mathrm{~kg}$ of pyrite into a vessel, after which $750 \mathrm{~mL}$ of cyanide solution was added at a concentration of $400 \mathrm{mg} \cdot \mathrm{L}^{-1}$ cyanide ion. The cyanide solution was obtained by dissolving $1.5 \mathrm{~g}$ of $\mathrm{NaCN}$ in $2000 \mathrm{~mL}$ of water, which meant a concentration of $0.8 \mathrm{~g} \cdot \mathrm{L}^{-1}$ of $\mathrm{CN}^{-}$ion.

The $p \mathrm{H}$ of the cyanide solution before contact with the pyrite was 10.3. After stirring the cyanide solution with the non-calcined pyrite for $5 \mathrm{~min}$, the $p \mathrm{H}$ was again measured using the inoLab laboratory $\mathrm{pH}$ meter. It was found that the $p \mathrm{H}$ dropped to 1.44 , which is why $5 \mathrm{~g}$ of lime was added and a 5 min stirring was again made. At a new $p \mathrm{H}$ measurement, it was 1.6. $10 \mathrm{~g}$ of lime was added and the stirring was continued for $5 \mathrm{~min}$. The procedure was repeated 5 times until finally $55 \mathrm{~g}$ of lime was added and the $p \mathrm{H}$ was set to 12.1 . 


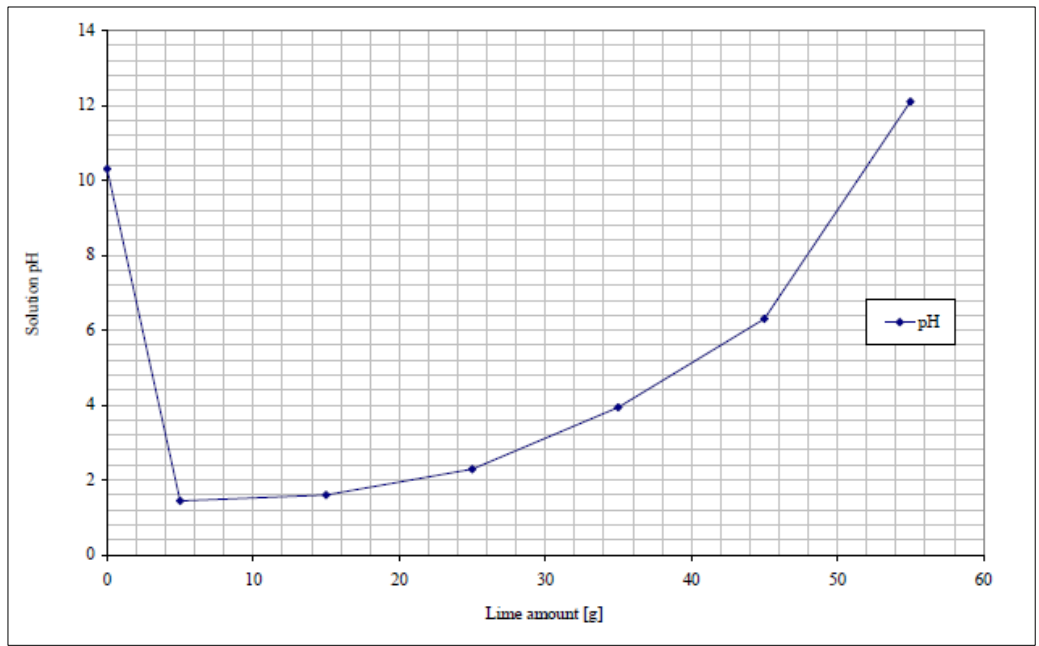

Figure 4. The variation of $p \mathrm{H}$ of the cyanide solution depending on the lime amount

After two hours of stirring the cyanide $(\mathrm{CN}-)$ ion dropped to $100 \mathrm{mg} \cdot \mathrm{L}^{-1}$, the $p \mathrm{H}$ of the solution was kept constant at a solution temperature of $25^{\circ} \mathrm{C}$. Determination of the cyanide free ion concentration of the cyanide lysates was done by titration with silver nitrate solution. The excess of silver ions was highlighted as follows: the precipitate is immediately filtered through a low porosity filter paper, taking $10-25 \mathrm{~mL}$ in a $250 \mathrm{~mL}$ Erlenmeyer. Add $0,5 \mathrm{~mL}$ of para-dimethylaminobenzaldehyde solution and titrate with $0.01 \mathrm{~N}$ silver nitrate solution or $0.05 \mathrm{~N}$ solution if more than $200 \mathrm{mg} \cdot \mathrm{L}^{-1}$ of ionic cyan up to yellow color turns in pink orange.

After two hours of stirring the ion cyanide content in the solution dropped to $100 \mathrm{mg} \cdot \mathrm{L}^{-1}$ and the gold content in the first slurry was $0.66 \mathrm{mg} \cdot \mathrm{L}^{-1}$. An amount of $\mathrm{NaCN}(0.3 \mathrm{~g})$ was added and stirring continued for $24 \mathrm{~h}$.

By prolonging the stirring range to $24 \mathrm{~h}$, the ion cyanide content dropped to $6.24 \mathrm{mg} \cdot \mathrm{L}^{-1}$, which is why $0.556 \mathrm{~g}$ of $\mathrm{NaCN}$ was added, and the gold content in the lime was $2.04 \mathrm{mg} \cdot \mathrm{L}^{-1}$.

After $48 \mathrm{~h}$ of stirring, the $\mathrm{CN}$ ion content dropped to $29 \mathrm{mg} \cdot \mathrm{L}^{-1}, 0.5244 \mathrm{~g}$ of $\mathrm{NaCN}$ was added, and the $\mathrm{Au}$ content in lime was $2.15 \mathrm{mg} \cdot \mathrm{L}^{-1}$. Stirring was continued for up to $72 \mathrm{~h}$, after which it was found that the $\mathrm{CN}$-ion content decreased only to $328 \mathrm{mg} \cdot \mathrm{L}^{-1}$ and the Au content was $2.72 \mathrm{mg} \cdot \mathrm{L}^{-1}$.

The variation of gold (a) / cyan (b) content in lime depending on stirring time is summarized by Figure 5.

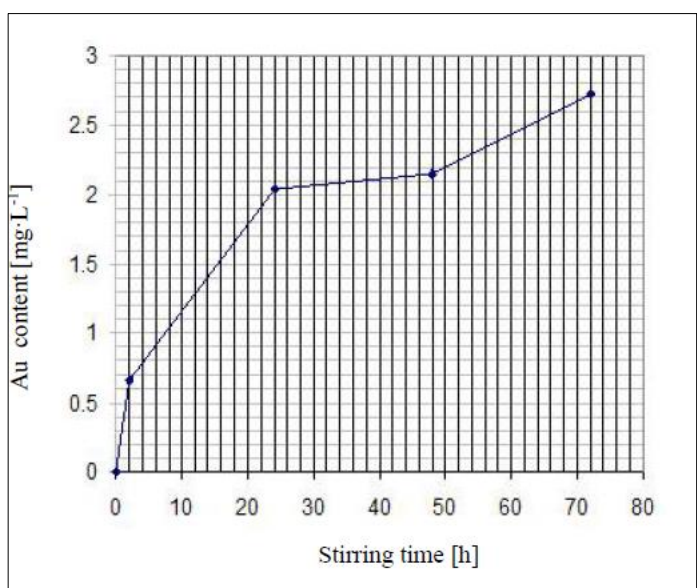

(a)

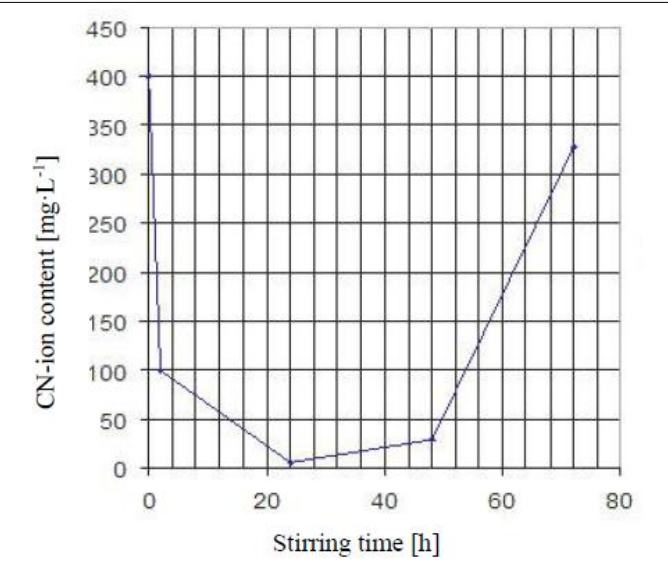

(b)

Figure 5. Variation of gold (a) and cyan (b) content in lime depending on stirring time 
The two charts illustrate that at beginning, when the material was not in contact with the cyanide solution, the gold content is null, but as the cyanide pyrite conditioning time increases, the gold content in the lime increases. The cyanide content in the initial lime is high $\left(400 \mathrm{mg} \cdot \mathrm{L}^{-1}\right)$, but after $2 \mathrm{~h}$ of stirring it drops to $100 \mathrm{mg} \cdot \mathrm{L}^{-1}$, which is why a new amount of cyanide was added to reach a cyanide content of $400 \mathrm{mg} \cdot \mathrm{L}^{-1}$, then 24 stirring hours drop back to $6.24 \mathrm{mg} \cdot \mathrm{L}^{-1}$. The cyanide content remains approximately constant after $72 \mathrm{~h}$ of stirring and $1.4 \mathrm{~g}$ of $\mathrm{NaCN}$ was added to the lime.

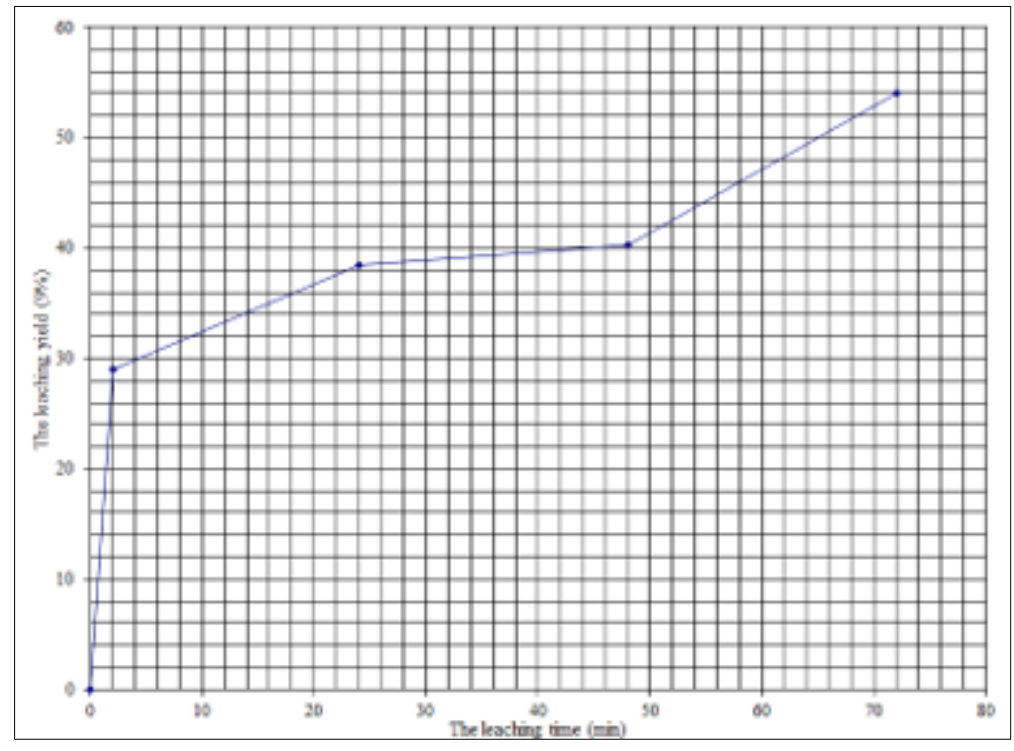

Figure 6. The leaching rating of the unroasted pyrite

The Figure 6 shows that the leaching rate in the unroasted pyrite's case is around $50 \%$.

The leaching of gold from roasted pyrite at 700 and $400^{\circ} \mathrm{C}$, was carried out with the help of rolling barge method, respectively. At the both working temperatures $500 \mathrm{~g}$ of roasted pyrite was processed under the same conditions as in the case of the unroasted pyrite leaching.

The leaching of gold from the roasted pyrite at $700^{\circ} \mathrm{C}$ was carried out with the help of the rolling barge method $[14,15]$.

In the first case the initial $p \mathrm{H}$ of the cyanide solution was 10.3 , which 5 min later, under continuous stirring, dropped to 6.72. When an amount of $5 \mathrm{~g}$ of lime was added and the sample was stirred for 5 min the $p \mathrm{H}$ increased to 12.4 (Figure7).

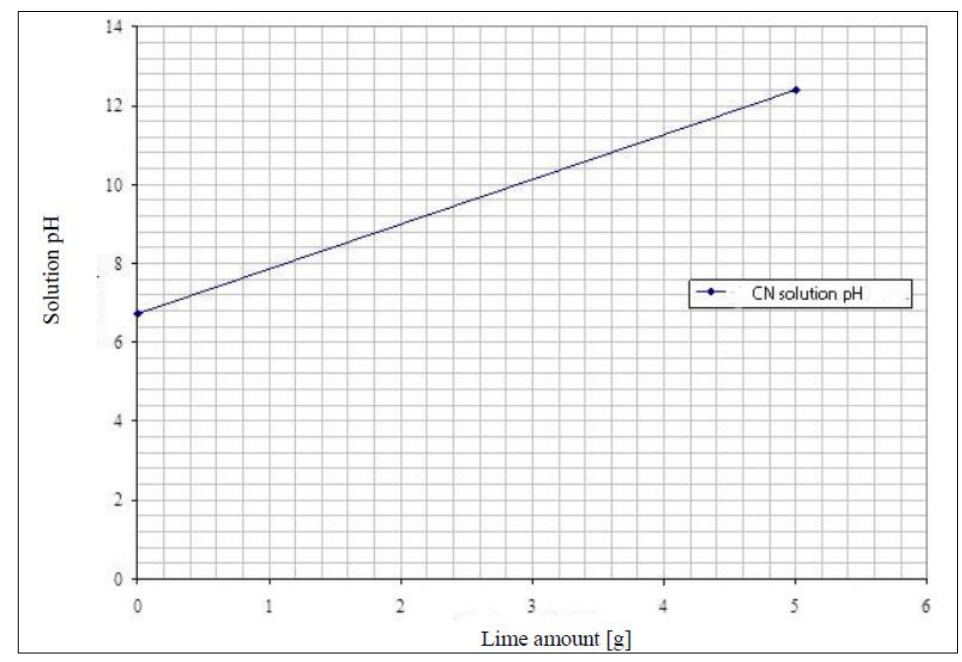

Figure 7. Variation of $p \mathrm{H}$ of the solution in contact with roasted pyrite at $700^{\circ} \mathrm{C}$ depending on the amount of lime 
After $2 \mathrm{~h}$ of stirring, the cyanide content was $108 \mathrm{mg} \cdot \mathrm{L}^{-1}$ and the gold content in the lime was 1.63 $\mathrm{mg} \cdot \mathrm{L}^{-1}$. Then $0.37 \mathrm{~g}$ of $\mathrm{NaCN}$ was added and stirring was continued for $24 \mathrm{~h}$, after which, by titration, was again determined the contain $139 \mathrm{mg} \cdot \mathrm{L}^{-1}$ of ionic cyan and the leaching content of gold was 3.28 $\mathrm{mg} \cdot \mathrm{L}^{-1}$. Further, an amount of $0.33 \mathrm{~g}$ of $\mathrm{NaCN}$ was added and stirring continued for up to $48 \mathrm{~h}$.

After $48 \mathrm{~h}$ of stirring the ionic cyan content was $280 \mathrm{mg} \cdot \mathrm{L}^{-1}$, which is why $0.153 \mathrm{~g}$ of $\mathrm{Na} \mathrm{CN}$ was added and the content of gold in the lime was $3.48 \mathrm{mg} \cdot \mathrm{L}^{-1}$. After the addition of $0.153 \mathrm{~g}$ of cyanide, the stirring continued for $72 \mathrm{~h}$. It was found that the cyanide ion content was not changed much and the content of gold in the lime was $4.32 \mathrm{mg} \cdot \mathrm{L}^{-1}$. Cyanide consumption on roasted pyrite was $0.885 \mathrm{~g} / 500$ $\mathrm{g}$ of material, which means $1.706 \mathrm{~g} \cdot \mathrm{kg}^{-1}$, ie $1,706 \mathrm{~kg} \cdot \mathrm{t}^{-1}$. It should be noted that in this case the lime was reduced from $110 \mathrm{~kg} \cdot \mathrm{t}^{-1}$ to $10 \mathrm{~kg} \cdot \mathrm{t}^{-1}$.

Figure 8 shows the above described variation of gold(a) and cyanide (b) content in lime depending on the stirring time of the roasted pyrite at $700^{\circ} \mathrm{C}$.

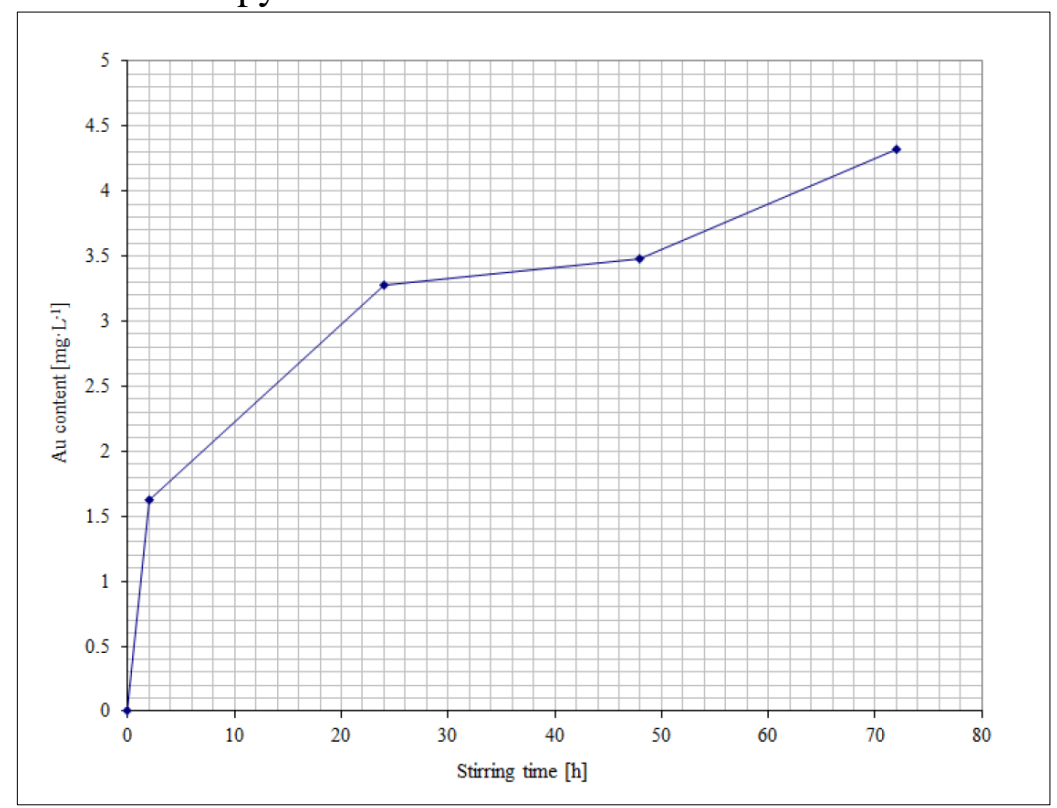

(a)

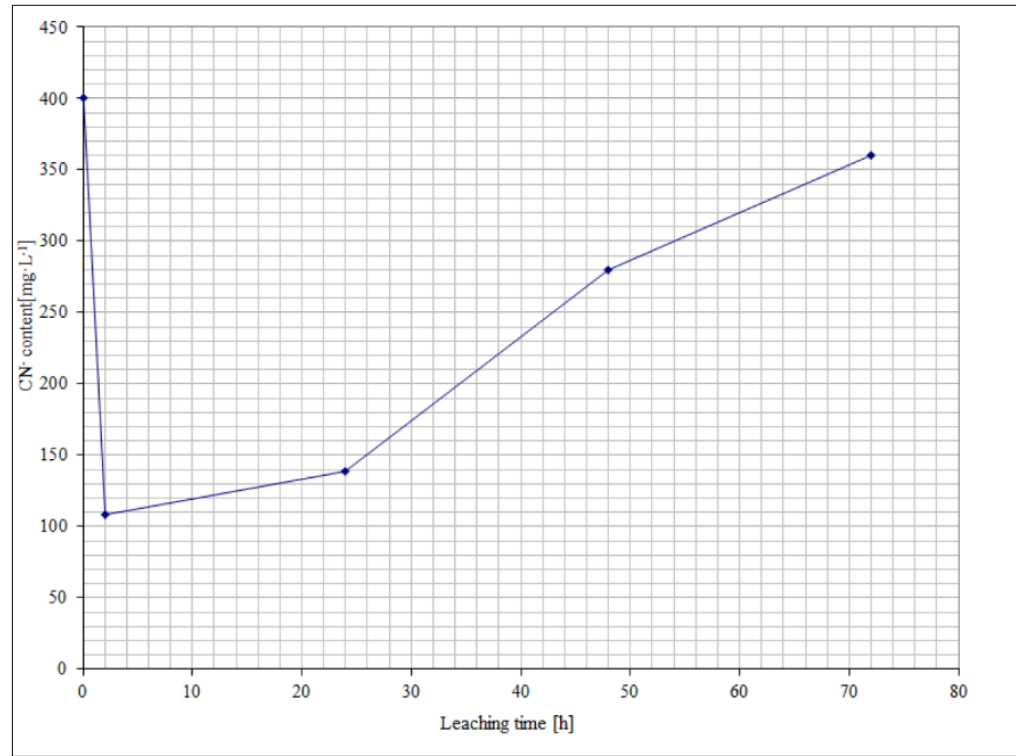

(b)

Figure 8. Variation of gold(a) and cyanide (b) contents in lime depending on the stirring time of the roasted pyrite at $700^{\circ} \mathrm{C}$ 


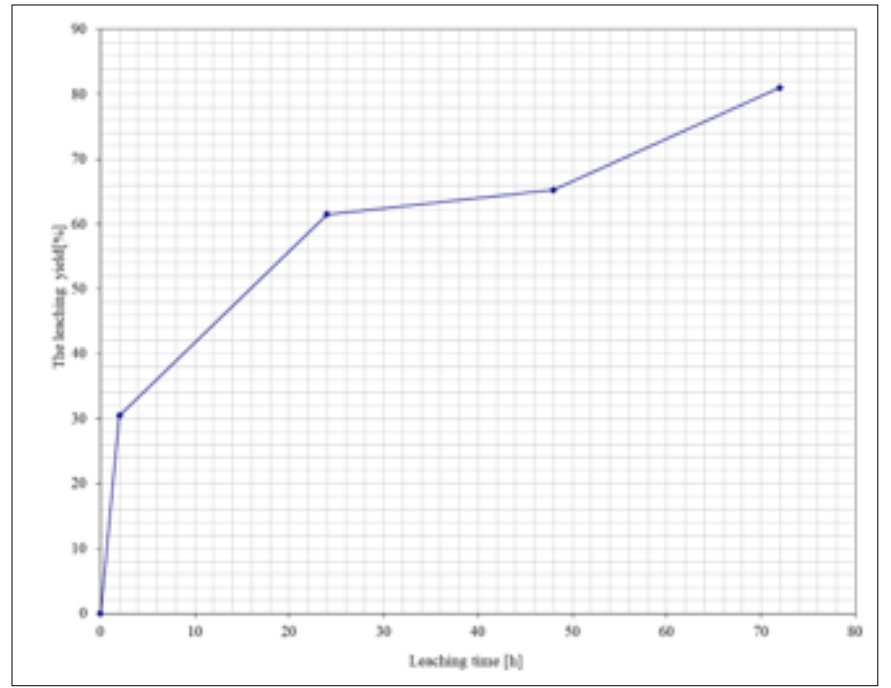

Figure 9. The leaching yield on the stirring time of the roasted pyrite at $700^{\circ} \mathrm{C}$

The Figure 9 shows that in the case of the roasted pyrite at $700^{\circ} \mathrm{C}$ the leaching rating can reach up to $81 \%$ with the reduction of cyanide and lime consumption.

In the second case the initial $p \mathrm{H}$ of the cyanide solution was 10.3, after stirring for $5 \mathrm{~min}$ it dropped to 2.52 (Figure 10). The $p \mathrm{H}$ of the solution reached 3.04, at the addition of $5 \mathrm{~g}$ of lime and after $5 \mathrm{~min}$ of stirring. The addition of lime in $5 \mathrm{~g}$ portions and stirring for $5 \mathrm{~min}$ was repeated until the $p \mathrm{H}$ reached 12.1 and the total amount of the added lime was $45 \mathrm{~g}$.

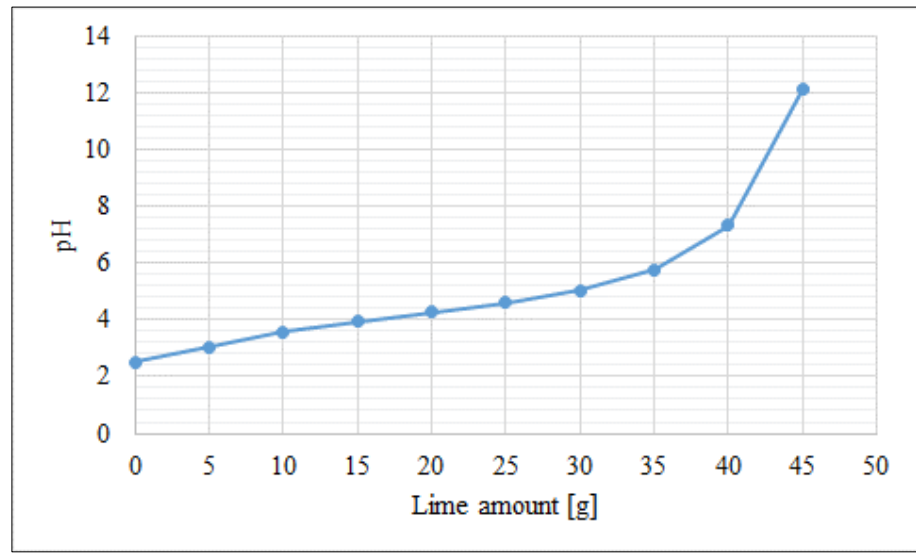

Figure 10. Variation of $p \mathrm{H}$ of the solution in contact with roasted pyrite at $400^{\circ} \mathrm{C}$ depending on the amount of lime

After $2 \mathrm{~h}$ of stirring, the cyanide content was $10.4 \mathrm{mg} \cdot \mathrm{L}^{-1}$ and the lime gold one was $1.55 \mathrm{mg} \cdot \mathrm{L}^{-1}$. An amount of $0.495 \mathrm{~g}$ of $\mathrm{NaCN}$ was added and the stirring was continued for $24 \mathrm{~h}$, after which, by titration, the cyan content was again determined at $16.6 \mathrm{mg} \cdot \mathrm{L}^{-1}$ and the gold content in the lime was $2.06 \mathrm{mg} \cdot \mathrm{L}^{-1}$. Further, an amount of $0.487 \mathrm{~g}$ of $\mathrm{NaCN}$ was added and stirring continued for up to $48 \mathrm{~h}$. After $48 \mathrm{~h}$ of stirring the ionic cyan content was $78.82 \mathrm{mg} \cdot \mathrm{L}^{-1}$, which is why another amount of $0.416 \mathrm{~g} \mathrm{NaCN}$ was added, and the gold content in the leachate was $2.15 \mathrm{mg} \cdot \mathrm{L}^{-1}$.

The stirring continued for $72 \mathrm{~h}$, but not before the addition of $0.416 \mathrm{~g}$ of cyanide. After $72 \mathrm{~h}$ it was found that the cyan ion content wasn't changed and the content of gold in lime was of $2.88 \mathrm{mg} \cdot \mathrm{L}^{-1}$. Cyanide consumption on roasted pyrite was $1.398 \mathrm{~g} / 500 \mathrm{~g}$ of material, which means $2.796 \mathrm{~g} \cdot \mathrm{kg}^{-1}$, i.e. $2,796 \mathrm{~kg} \cdot \mathrm{t}^{-1}$. It should be noted that in this case the lime consumption was $90 \mathrm{~kg} \cdot \mathrm{t}^{-1}$. Variation of gold 
(a) and cyanide (b) contents in lime depending on the stirring time of the roasted pyrite at $400^{\circ} \mathrm{C}$ is pointed out in Figure 11.

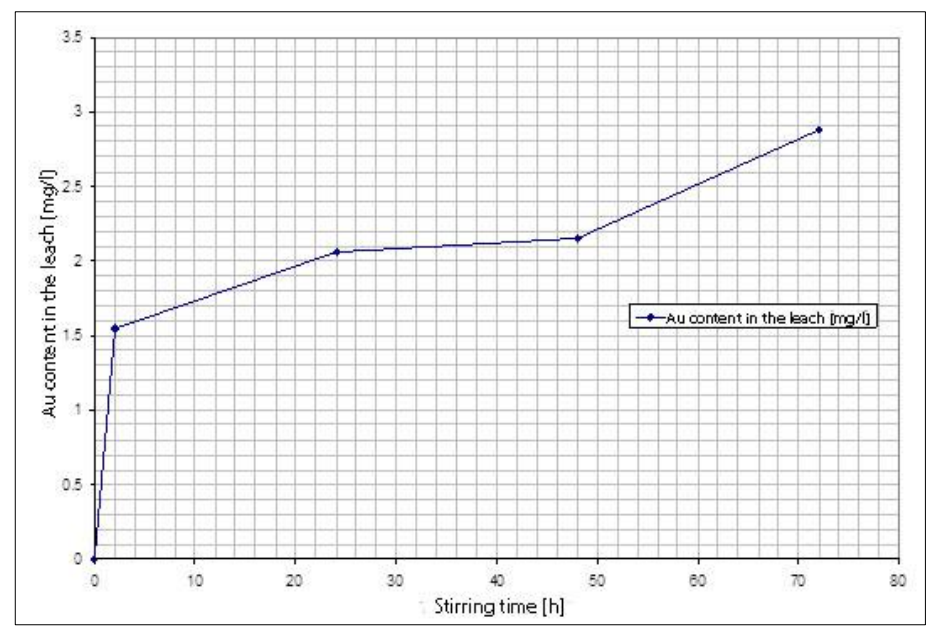

(a)

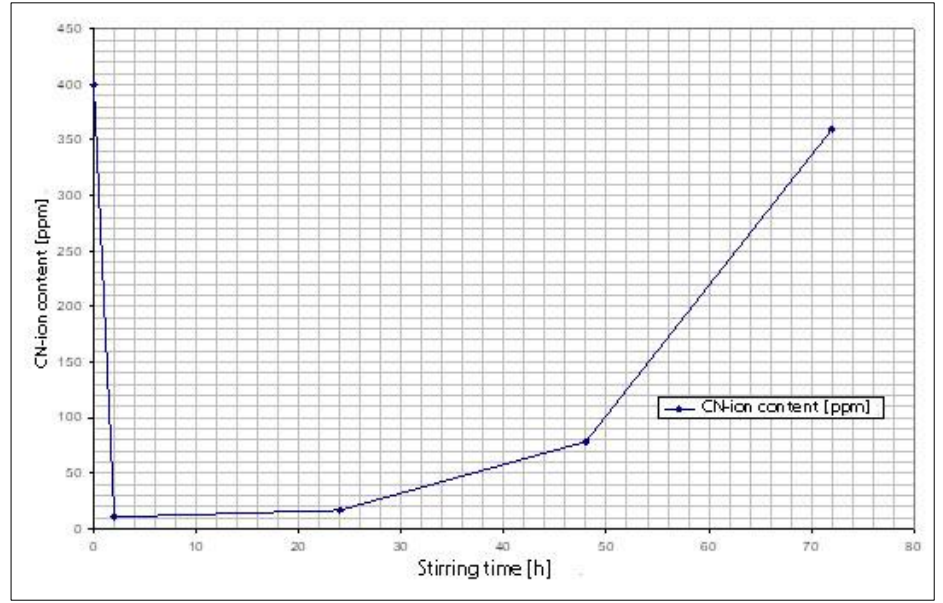

(b)

Figure 11. Variation of gold (a) and cyanide (b) contents in lime depending on the stirring time of the roasted pyrite at $400^{\circ} \mathrm{C}$

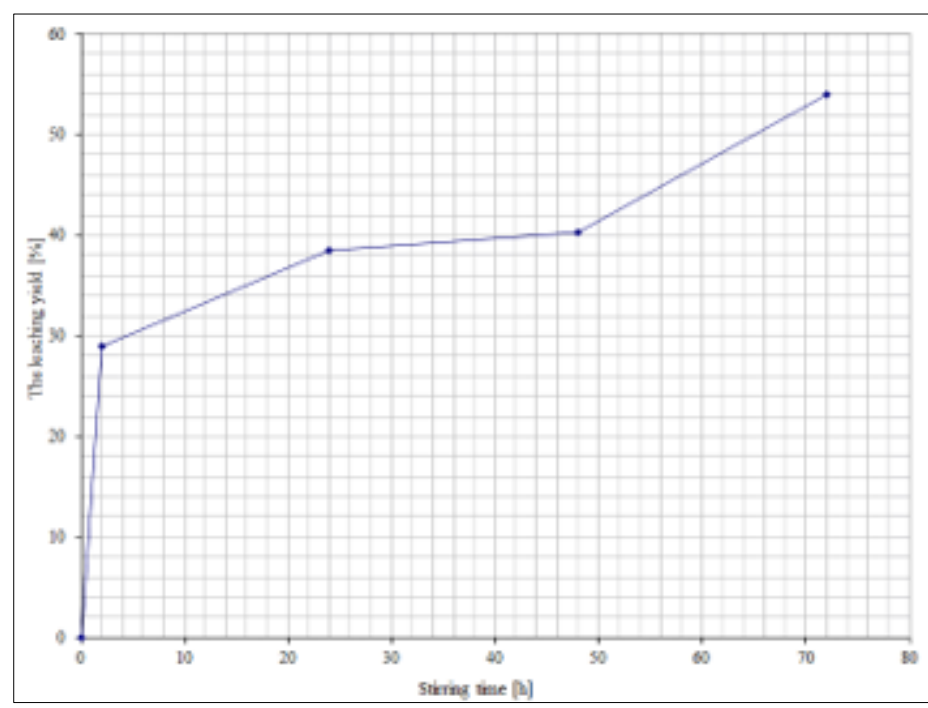

Figure 12.The leaching yield depending on the stirring time of the roasted pyrite at $400^{\circ} \mathrm{C}$ 
Figure 12 shows that for the pyrite roasted at $400^{\circ} \mathrm{C}$, the leaching yield can reach up to $54 \%$ with a slight reduction in cyanide and lime consumption.

An overall representation of lime and cyanide consumption, and also of the leaching rating on unroasted and roasted pyrites is illustrated in Figure 13 and 14, respectively.

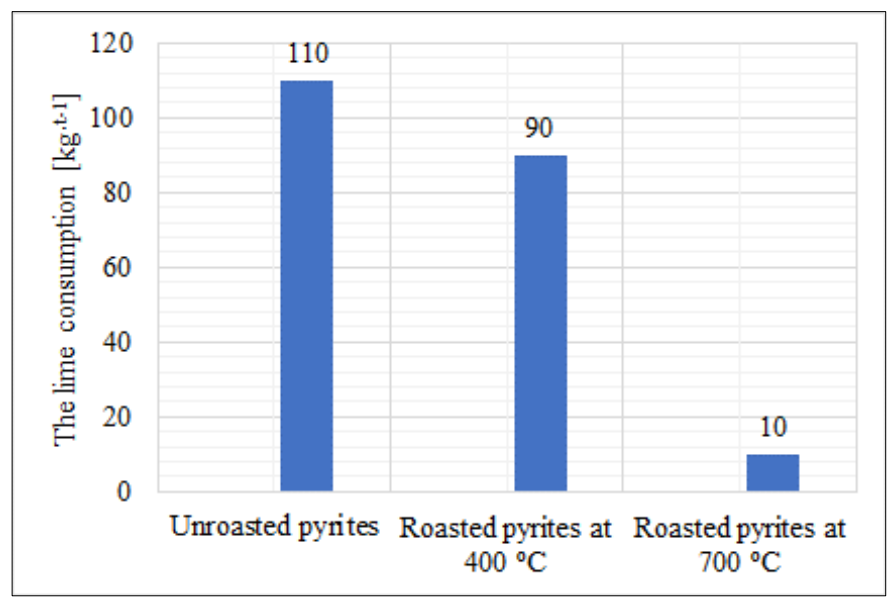

(a)

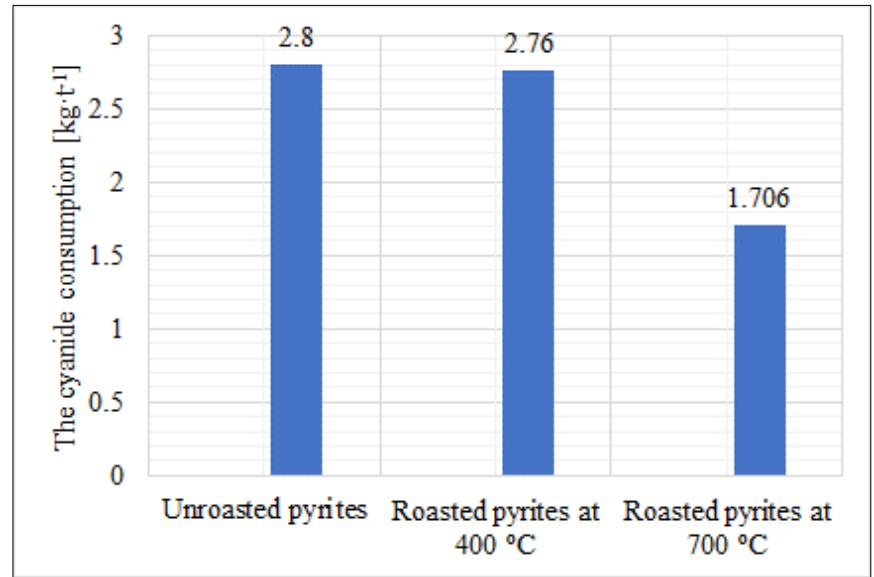

(b)

Figure 13. The variation of lime (a) and cyanide (b) consumption depending on the type of cyanide pyrites

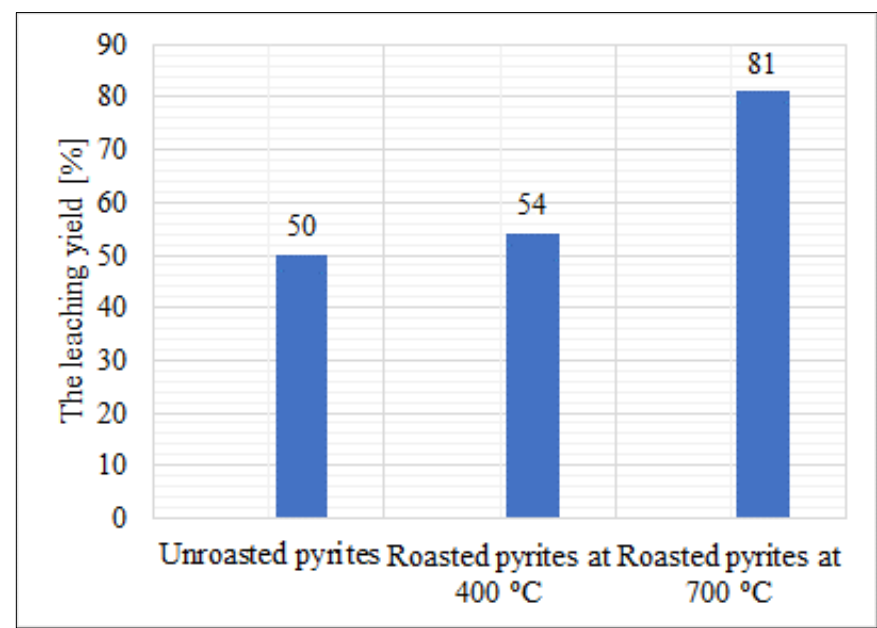

Figure 14. The variation of leaching yield depending on the type of cyanide pyrite 


\section{Conclusions}

The following conclusions can be drawn from the researches:

- During the roasting process it was found that the pyrite tends to heat in about 16 min at a temperature of $750^{\circ} \mathrm{C}$, which is why it was necessary to stop the energy supplied by the magnetron to avoid overheating the system.

- It has also been found that during the roasting process there is a tendency for slagging and production of slag that negatively influence the fluidization process.

- The effects of crack and cavity microwaves on pyrite crystals can be seen in plans obtained from electro microscopic analyzes.

- After performing comparative cyanidation tests on unroasted and roasted pyrites at $400^{\circ} \mathrm{C}$ and $700^{\circ} \mathrm{C}$, respectively, it was found that there was no significant reduction in lime and cyanide consumption for roasted pyrite at $400^{\circ} \mathrm{C}$ but for the roasted pyrite at $700^{\circ} \mathrm{C}$ the consumption of lime is reduced from $110 \mathrm{~kg} \cdot \mathrm{t}^{-1}$ to $10 \mathrm{~kg} \cdot \mathrm{t}^{-1}$, cyanide is reduced from $2.8 \mathrm{~kg} \cdot \mathrm{t}^{-1}$ to $1.76 \mathrm{~kg} \cdot \mathrm{t}^{-1}$, and yields of leaching increase from $50 \%$ for unroasted pyrite at $81 \%$ for roasted pyrite.

- The indefinite problems are: avoiding the production of slag in the resonant cavity and the decrease of the sulfur content below $3 \%$, which would allow the testing of the solubilization process by wet chlorination, in which case the cyanide use would be abandoned.

\section{References}

1.JAVAD KOLEINI, S.M., BARANI, K., Microwave Heating Applications in Mineral Processing. In: The Development and Application of Microwave Heating, W. Cao (Ed.), IntechOpen, Rijeka, 2012, p. 79-104.

2.PENG, Z., HWANG, J.Y., Microwave-assisted metallurgy, International Materials Reviews, 60(1), 2015, p. 30-63.

3.ADAMS, M., Gold Ore Processing. Project Development and Operations, vol. 15, 2nd edition, Elsevier Science, 2016.

4.YANG, Y., Yin, W., JIANG, T., XU, B., LI, Q., Research on Process of Hydrometallurgical Extracting $\mathrm{Au}, \mathrm{Ag}$, and $\mathrm{Pd}$ from Decopperized Anode Slime. In: Rare Metal Technology, N. Neelameggham, S. Alam, H. Oosterhof, A. Jha, D. Dreisinger, S. Wang (Eds), Springer, 2016, p. 107114.

5.LI, Q., ZHANG, Y., LIU, X., XU, B., YANG, Y., JIANG, T., Improvement of gold leaching from a refractory gold concentrate calcine by separate ore treatment of coarse and fine size fractions, Minerals, 7, 2017, Article 80.

6.ZHANG, Y., LI, Q., LIU, X. XU, B., YANG, Y., JIANG, T., A thermodynamic analysis on the roasting of pyrite, Minerals, 9, 2019, Article 220.

7.XU, B., YANG, Y., LI, Q., LI, G., JIANG, T., Fluidized roasting-stage leaching of a silver and gold bearing polymetallic sulfide concentrate, Hydrometallurgy, 147-148, 2014, p. 79-82.

8.ÖRGÜL, S., ATALAY, Ü., Reaction chemistry of gold leaching in thiourea solution for a Turkish gold ore, Hydrometallurgy, 67, 2002, p. 71-77.

9.POPESCU, A.M., SOARE, V., DEMIDENKO, O., MORENO, J.M.C., NEACSU, E.I., DONATH, C., BURADA, M., CONSTANTIN, I., CONSTANTIN, V., Recovery of silver and gold from electronic waste by electrodeposition in ethaline ionic liquid, Rev. Chim., 71(1), 2020, p. 122-132.

10.BOYABAT, N., ÖZER, A., BAYRAKCEKEN, S., GÜLABOGLU, M., Thermal decomposition of pyrite in the nitrogen atmosphere. Fuel Process, Technol., 85, 2005, p.179-188.

11.OZKAN, A., AYDOGAN, S., AKDEMIR, U, Bacterial leaching as a pre-treatment step for gold recovery from refractory ores, Fizykochemiczne Problemy Mineralurgii, 32, 1998, p. 173-181.

12.PICKLES, C., Microwaves in extractive metallurgy: Part 2-A review of applications, Mineral Engineering, 22(13), 2009, p. 1112-1118.

13.USLU, T., ATALAY, Ü., Microwave heating of coal for enhanced magnetic removal of pyrite. Fuel Process. Technol, 85, 2004, p. 21-29. 
14.HUANG, J., ROWSON, N., Heating characteristics and decomposition of pyrite and marcasite in a microwave field, Mineral Engineering, 14, 2001, p. 1113-1117.

15.MA, S., LUO, W., MO, W., SU, X., LIU, P., YANG, J., Removal of arsenic and sulfur from a refractory gold concentrate by microwave heating, Mineral Engineering, 23, 2010, p. 61-63.

16.AMANKWAH, R., KHAN, A., PICKLES, C., YEN, W., Improved grindability and gold liberation by microwave pretreatment of a free-milling gold ore, Miner. Process. Extr. Metall, 114, 2005, p. 3036.

17.IVANUŞ, GH., TODEA, L., POP, AL., NICOLA, S., DAMIAN GH., Ingineria fluidizării, Ed. Tehnică, 1996, Bucharest.

18.WODCOOK J.T., SPAROW G.J., BRADHURST D.H., Possibilities for using microwave energy in the extraction of gold. Proceedings 1st Australian Symposium on Microwave Power Applications, Wollongong, Australia, 2000

19.MCGILL S.L., WALKIEVICZ J.W., Application of microwave energy in extractive metallurgy, Journal of Microwave Power and Electromagnetic Energy, 22 (3), 1987, p. 175-177

$\overline{\text { Manuscript received: } 27.02 .2020}$ 